ISSN:2528-9527

E-ISSN: 2528-9535

YIl Year: 11

Cilt Volume: 18

Sayı Issue: 39

Uluslararası Toplum Araştırmaları Dergisi International Journal of Society Researches

Temmuz July 2021

Makalenin Geliş Tarihi Received Date: 12/12/2020 Makalenin Kabul Tarihi Accepted Date: 10/02/2021

\title{
İşyeri Nezaketsizliği: Ulusal Literatür Üzerine Bir İçerik Analizi
}

DOI: $10.26466 /$ opus. 839745

*

\author{
Çă̆daș Ișıkay * - Soner Taslak ** \\ * Öğr.Gör.Dr., Muğla Sıtkı Koçman Üniversitesi, Sağlık Bilimleri Fakültesi, Muğla Türkiye \\ E-Posta: cagdasi@mu.edu.tr \\ ORCID: $0000-0001-8983-8130$ \\ ** Prof.Dr., Muğla Sıtkı Koçman Üniversitesi, İ̈BF, Muğla Türkiye \\ E-Posta: sonertaslak@mu.edu.tr \\ ORCID: $\underline{\text { 0000-0002-6895-8915 }}$
}

Öz

İsyeri nezaketsizliğinin çalışanlar arasında neden ortaya çıktı̆̆ı, hangi doğrultuda geliştiği, ne gibi etkilerinin olduğu ve örgütlerin geliştirdiği çözüm önerilerinin tespiti ülkemiz açısından önemli olabilir. Çalışmanın amacl, işyeri nezaketsizliğine yönelik olarak yapılan araştırmaları, yıl, tür, nitelik, kullanılan ölçek, veri toplama tekniği, kullanılan dil, örneklem grubu, yapılan analiz teknikleri, ilişkili bağımlı-bağımsız değişkenler, değişkenler arasındaki korelasyonun yönü gibi özellikler açısından incelemek ve bu yolla literatüre katkı sağlamaktır. Bu araştırmada, işyeri nezaketsizliği ile ilgili makale, tez, bildiri ve kitap bölümlerinden oluşan otuz yedi çalışma incelenmiştir. Bu incelemede, nitel araştırma yöntem türlerinden olan içerik analizi kullanılmıştır. Sonuç olarak; işyeri nezaketsizliği ile ilgili araştırmaların yıllar geçtikçe arttığı, nicel araştırmaların çoğunlukta olduğu, sağlık çalışanları örnekleminin daha çok tercih edildiği, uluslararası ölçeklerin daha çok kullanıldığı saptanmıştır. Iş̧yeri nezaketsizliği kavramının en yüksek oranda, iş doyumu, işten ayrılma niyeti ve makyavelist kişilik ile ilişkilendirildiği belirlenmiştir. İşyeri nezaketsizliğinin iş doyumu ile negatif yönde ilişkili olduğu buna karşın işten ayrılma niyeti ve makyavelist kişilik ile pozitif yönde ilişkili olduğu saptanmıştır. Ilaveten, araştırmacılara gelecekte yapılabilecek çalışmalar konusunda önerilerde bulunulmuştur.

Anahtar Kelimeler: İşyeri Nezaketsizliği, Nitel Araştırma, İ̧crik Analizi 
ISSN:2528-9527

E-ISSN: 2528-9535

YIl Year: 11

Cilt Volume: 18

Sayı Issue: 39

Uluslararası Toplum Araştırmaları Dergisi

International Journal of Society Researches

Temmuz July 2021

Makalenin Gelis Tarihi Received Date: 12/12/2020

Makalenin Kabul Tarihi Accepted Date: 10/02/2021

\title{
Workplace Incivility: A Content Analysis on National Literature
}

*

\begin{abstract}
It may be important for our country to determine why workplace incivility occurs among employees, in what direction it develops, what effects it has, and the solution proposals developed by organizations. The aim of the study is to examine the studies conducted for workplace incivility in terms of features such as year, type, quality, scale used, data collection technique, language used, sample group, analysis techniques, related dependent-independent variables, direction of correlation between variables and to contribute to the literature in this way. In this study, thirty-seven studies consisting of articles, theses, papers and book chapters about workplace incivility were examined. Content analysis, one of the qualitative research methods, was used in this study. As a result; it has been determined that the studies on workplace incivility have increased over the years, quantitative studies are the majority, the sample of healthcare professionals is more preferred, and international scales are used more. It has been determined that the concept of workplace incivility is associated with job satisfaction, intention to quit and Machiavellian personality at the highest rate. It was found that workplace incivility was negatively correlated with job satisfaction, but positively correlated with the intention to quit and Machiavellian personality. In addition, suggestions were made to researchers about future studies.
\end{abstract}

Keywords: Workplace Incivility, Qualitative Research, Content Analysis 


\section{Giriş}

İşyeri nezaketi, çalışanlar arasındaki saygı normlarının korunmasında yardımcı bir yaklaşımdır. Çalışma arkadaşlarıyla olumlu bağlantılar kurmak, ilişkileri geliştirmek, huzur ortamı oluşturmak ve onların penceresinden olaylara bakabilmek için gerekli olan davranışlar, işyeri nezaketini ifade eder. İsyeri nezaketsizliği ise, işyerinde kabul gören sayg1 normlarını ihlal eden, bireyde saygısızlığa uğradığı yönünde duygu ve düşüncelerin gelişmesine neden olan, üzüntü veren ve incitici olabilen sözlü-sözsüz, pasif, imalı, dolaylı, düşük yoğunluklu davranışlardır (Andersson ve Pearson, 1999, s.453).

Araştırmalar, işyeri nezaketsizliğinin oldukça yaygın olduğunu ve gün geçtikçe de arttığını bildirmektedir. Gallus ve arkadaşları (2014, s.148) yaptıkları bir araştırmada, katılımcıların yüzde 85'inin son bir yıl içerisinde işyeri nezaketsizliği yaşadıklarını, yüzde 77,8 'inin işyerinde nezaketsiz davranıslar sergilediklerini ve yüzde 71,8 'inin hem nezaketsizlik yaşayıp hem de nezaketsiz davranışlar sergileyerek işyeri nezaketsizliğine katkıda bulunduklarını ortaya koymuştur. Cortina ve arkadaşları (2001, s.64), katılımcıların yüzde 71'inin son beş yılda en az bir kez, yüzde 39'unun bir ya da iki kez, yüzde 6'sının iki ya da daha fazla sayıda, küçümsenme, aşağılanma, göz ardı edilme, hiçe sayılma, mesleki kanaatlerinden şüphe duyulma, dışlanma gibi işyeri nezaketsizliği davranışlarına maruz kaldıklarını tespit etmiştir. Nezaketsizliğin, çalışanların verimliliğini azaltma, ekonomik kayıplara neden olma, tıbbi maliyetleri arttırma, olumsuz örgüt iklimine yol açma gibi yıkıcı etkilerinin olduğu bildirilmektedir.

İşyeri nezaketsizliğine ilişkin algının her kültür için farklılık gösterebileceği ancak, her örgüt için ortak sayg1 normlarının geliştirilebileceği ve bu normlara uygun davranmanın önemi açıkça görülmektedir. İşyeri nezaketsizliği, başlangıçta saldırganlık, zorbalık, mobbing, şiddet gibi kesin belirtileri ve etkileri olan bir durumu ifade etmese bile zamanla ortaya çıkacak birikimli etki çalışanlara, örgüte hatta örgütler arasında yaygınlaşmaya bağlı ülkeye zarar verebilir (Pearson, Andersson ve Porath, 2000, s.124-130). Başlangıçta hafif, üstesinden gelinebilir gibi görünen işyeri nezaketsizliği olgusunun, zamanla 
şiddetlenebileceği ve olumsuz etkileri hakkında yapılan araştırmalar konuya olan ilginin artmasını sağlamıştır.

\section{İşyeri Nezaketsizliği}

Andersson ve Pearson, ilk defa 1999 yllında işyeri nezaketsizliğini tanımlamıştır. Bu tanıma göre işyeri nezaketsizliği; 'hedeflenen bireye zarar verme niyetinde belirsizlik, işyeri saygı kurallarını ihlal etme ve düşük şiddette görülen bir sapma davranışını' ifade etmektedir. Nezaketsizlikte kaba davranışlar ile saygısızlık ön plandadır. Bu tanımla birlikte işyeri nezaketsizliğinin 3 tane önemli özelliği göze çarpmaktadır. Bu özelliklerden ilki, örgüt kurallarının ve çalışanlar arasındaki karşılıklı saygının ihlal edilmesidir. İkinci özellik, hedefe zarar verme niyetinin belirsiz olmasıdır. Yani, saldırganlık, zorbalık gibi durumlarda açık olarak ortaya konulabilen zarar verme niyetini, işyeri nezaketsizliğinde açık bir şekilde teşhis etmek pek mümkün değildir. Dolayısıyla nezaketsiz davranışlar sergileyen taraf, bu durumu kolayca inkar edebilir ya da hedefin kişisel hassasiyetine atfedebilir. Her ne kadar zarar verme niyeti belirsiz olsa ya da herhangi bir zarar verme niyeti olmaksızın bilgisizlikten kaynaklı nezaketsiz davranışlar sergilense bile, bu durum hedefin zarar görmeyeceği anlamına gelmez. Yani niyet hangi durumda olursa olsun, nezaketsiz davranışa maruz kalan hedef, çeşitli yönlerden (moral bozukluğu, verimlilikte düşme vb.) zarar görebilir. Üçüncü özellik ise, düşük şiddete sahip olmadır. İşyerinde görülen olumsuz davranışlar arasındaki saldırganlık, şiddet ve zorbalık, daha şiddetli durumları ifade ederken, nezaketsizlikte düşük yoğunluk söz konusudur (Andersson ve Pearson, 1999; Pearson vd., 2001).

İşyeri nezaketsizliğinin nasıl geliştiği, Anderson ve Pearson (1999, s.457-463) tarafından ortaya konulan 'nezaketsizlik sarmalı' ile açıklanmıştır. Bu sarmala göre işyeri nezaketsizliği; nezaketsiz davranışlar sergileyen taraf ile bu nezaketsiz davranışlara maruz kalan, nezaketsizliği fark eden ve nezaketsiz bir davranışla karşılık veren taraf arasında zaman içerisinde sabit kalan, artarak devam eden ya da kademeli olarak gelişen bir süreçtir. Bu süreçte öncelikle, saygı kurallarının ihlal edildiği, zarar verme niyetinin belirsiz olduğu ve düşük düzeyli şiddet içeren davranışların sergilendiği hafif şiddetli bir durum vardır. Bu 
durum, nezaketsizliğin hedefinde olan bireyin, kimlik tehdidi algılaması sonrasında daha yoğun tepkiler vererek zarar verme niyetinin açığa çıktığı ve üretkenlik karşıtı davranışlara geçişi kapsayan bir duruma dönüşür. Bu aşamada, nezaketsizlik için eşik olarak görülen 'tepe' noktasının aşıldığı ve daha yıkıcı davranışlara geçildiği kabul edilir.

Pearson ve arkadaşları (2000, s.123-137), nezaketsizlik sürecinin taraflar arasında aynı şiddette verilen tepkilerle sabit bir şekilde ya da artan şiddetteki tepkilerle tırmanarak yaşanabileceğini bildirmiştir. Bunların dışında kademeli olarak da bu sürecin gerçekleşebileceğini ortaya koymuşlardır. Kademeli yaklaşımlardan biri olan 'dolaylı kaydırım' modeline göre, iki taraf arasında gerçekleşen nezaketsiz davranışlara tanık olan ya da duyan diğer bir çalışanın da başka bir çalışana nezaketsiz davranması söz konusudur. Diğer bir model olan 'doğrudan kaydırım' modelinde ise, her üst durumundaki bireyin astına nezaketsiz davranması şeklinde gerçekleşir. Son kademeli model ise, 'söylenti-dedikodu' modelidir. Buna göre nezaketsizliğe uğrayan birey, yaşadıklarını çalışma arkadaşları, astları, üstleri ve aileleriyle paylaşmak suretiyle nezaketsizliğin etkilerinin daha geniş bir alana yayılmasına yol açabilir.

Yapılan araştırmalar, çalışanların hangi tür nezaketsiz davranışlarla karşılaştıklarını ortaya koymuştur. $\mathrm{Bu}$ davranışlar arasında; selamlaşmamak, bağırarak konuşmak, konuşmasını kesmek, kararlarını dikkate almamak, hakaret edilmesi, başkalarının eşyalarını izinsiz kullanma, saygısız hitaplarda bulunma, grup aktivitelerinden dişlama, çatışma ortamı oluşturacak söylemlerde bulunulması, ortak kullanılan alanları dağınık bırakmak, güvenilirliği sarsıcı imalarda bulunmak, olumsuz mesajlar göndermek, dedikodu yapmak, toplantıların düzenini bozmak, önemli bilgilerin saklanması vb. sayılabilir (Pearson vd., 2000, s.126; Porath ve Pearson, 2010, s.64 ).

İşyeri nezaketsizliğinin hem bireyleri hem de örgütleri etkilediği çeşitli araştırmalarla saptanmıştır. Bireysel etkiler arasında; streste (Dion, 2006, s.89; Lim ve arkadaşları, 2008, s.100), tükenmişlikte (Oyeleye vd., 2013, s.540), iş-aile çatışmasında (Lim ve Lee, 2011, s.101), sağlık sorunlarında artış (Hershcovis, 2011, s.508), bilişsel yetilerde (Porath ve Pearson, 2010, s.65), iş arkadaşına yardım etme davranışlarında (Ismail, 2011, ss.12-16), işte gösterilen çabada (Logan, 2016, s.50), iş doyumunda (Welbourne vd., 
2015, s.211), örgüte bağlllıkta (Spence Laschinger vd., 2009, s.306) azalma olduğu belirlenmiştir. Bunların yanı sıra işyeri nezaketsizliğinin, ekip çalışmasına (Ricciotti, 2016, s.3) ve güven ortamına zarar verdiği de (Logan, 2016, s.50) tespit edilmiştir. Örgütsel etkiler arasında; işe devamsızlıkta (Khadjehturian, 2012, s.638; Pearson vd., 2000, s.130), işten ayrilma niyetinde (Huang ve Lin, 2019, s.49), adaletsizlik algisında (Lim ve Lee, 2011, s.101; Pearson vd., 2000, s.130), yönetsel ve yasal problemlerde artış (Pearson ve Porath, 2005, s.11; Porath ve Pearson, 2010, s.69; Porath ve Pearson, 2013, s.118), iş performansında, verimlilikte ve kalitede azalma (Logan, 2016, s.50; Pearson ve Porath, 2005, s.11) ve örgüt kültüründe bozulma (Pearson ve Porath, 2005, s.8) olduğu belirlenmiştir.

$\mathrm{Bu}$ açıklamalardan yola çıkarak, işyeri nezaketsizliğinin örgütlerde sıklıkla yaşandığı, dolaylı, muğlak ve düşük yoğunluklu özelliklerinden dolayı hem çalışanlar hem de yöneticiler tarafından kolaylıkla belirlenemediği, yasal düzenlemelerden yoksun olduğu, özellikle uzun vadeli etkilerinin oldukça yıkıcı olduğu ifade edilebilir. İşyeri nezaketsizliğinin çalışanlar arasında neden ortaya çıktığı, hangi doğrultuda ilerlediği, ne gibi etkilerinin olduğu ve örgütlerin geliştirdiği çözüm önerilerinin tespiti ülkemiz açısından da önemli olabilir. Bu nedenle ülkemizde nezaketsizliğe yönelik olarak hangi araştırmaların yapıldığını ve bilimsel yaklaşımların ne yönde ilerlediğini tespit etmek gerekir. $\mathrm{Bu}$ yaklaşımlar çerçevesinde araştırmanın amacl; işyeri nezaketsizliğine yönelik olarak yapılan araştırmaların, yılı, türü, niteliği, ölçek, veri toplama yöntemi, kullanılan dil, örneklem grubu, uygulanan analiz yöntemleri, bağımlı-bağımsız değişkenler ve değişkenler arasındaki korelasyonun yönünü inceleyerek literatüre katkı sağlamaktır.

\section{Yöntem}

\section{Araştırmanın Kapsamı}

Araştırmada, ülkemizde Haziran 2020 tarihine kadar 'işyeri nezaketsizliğgi' kavramıla ilgili bilimsel dergilerde yayınlanmış olan makaleler, hazırlanmış olan yüksek lisans-doktora tezleri, kongrelerde sunulmuş bildiriler ve kitap bölümleri incelenmiştir. Bu incelemede, nitel araştırma yöntem türlerinden olan içerik analizi kullanılmıştır. 


\section{Araştırmanın Soruları}

Araştırmanın amacı göz önünde bulundurularak, işyeri nezaketsizliği kavramına yönelik olarak aşağıdaki sorulara cevap aranmıştır. Bunlar;

- Araştırmalar, yayınlandığı yıllara göre nasıl bir dağılım göstermektedir?

- Araştırmaların türü nedir?

- Araştırmalar, nitelik açısından nasıl bir dağılım göstermektedir?

- Araştırmalarda kullanılan ölçekler hangileridir?

- Araştırmalarda kullanılan veri toplama teknikleri hangileridir?

- Araştırmalar hangi diller kullanılarak yazılmıştır?

- Araştırmaların yürütüldüğü örneklem grupları hangileridir?

- Araştırmalarda kullanılan analiz teknikleri nelerdir?

- İşyeri nezaketsizliği bağımlı ve bağımsız değişken olarak ele alındığı araştırmalarda hangi değişkenlerle ilişkilendirilmiştir?

- İşyeri nezaketsizliği kavramının, diğer değişkenlerle oluşturduğu korelasyonun yönü nedir?

\section{Verilerin Toplanması}

$\mathrm{Bu}$ araştırmada incelenecek makaleler, bildiriler ve kitap bölümleri için, SOBIAD, ULAKBIM Sosyal ve Beşeri Bilimler ve Google Scholar veri tabanları, tezler için ise YÖK'ün Ulusal Tez Merkezi Haziran 2020 itibariyle taranmıştır. Tarama sırasında; 'işyeri nezaketsizliği', 'işyeri kabalığı', 'nezaketsizlik', 'kabalık', 'meslektaş nezaketsizliğii' ifadeleri kullanılmıştır. Ulaşılan araştırmalar arasından tez ve makalelere öncelik verilmiş ve her araştırmanın bir kereye mahsus olarak değerlendirme kapsamına alınmasına özen gösterilmiştir. Bu doğrultuda tezlerden türetilen üç makale ve makalelerle bağlantılı dört bildiri değerlendirme dışı bırakılmıştır. Bir tane tez, erişime açılmadığı için değerlendirme dışı bırakılmış ancak, bu tezden üretilen iki makale değerlendirmeye alınmıştır.

İnceleme sonucunda on üç (13) adet lisansüstü teze, on altı (16) adet makaleye, yedi (7) adet bildiriye ve bir (1) adet kitap bölümüne ulaşılmıştır. Değerlendirmeye alınan tezlerin, 8'si yüksek lisans (Akcakavaklı, 2019; Bayrakci, 2019; Bolat, 2018; Gültaç, 2019; Güzel, 2019; Hüner, 2019; İlgın, 2019; Kumral, 2017) 5’i doktora (Baran, 2019; Erdaş, 
2016; Işıkay, 2018; Keçeci, 2017; Kızıloğlu, 2019) tezidir. Bu çalışmada on altı (16) adet makale (Batga ve Ceyhan, 2019; Delen, 2010; Demirsel, ve Erat, 2019; Gök, Karatuna ve Başol, 2019; Göktepe ve Keleş, 2019; Kanten, 2014; Kaya, 2015; Kumral ve Çetin, 2016; Kutlu ve Bilgin, 2017; Küçük ve Çakıcı, 2018a; Küçük ve Çakıcı, 2018b; Polatcı ve Özçalık, 2013; Taştan, 2014; Üstün ve Ersolak, 2020a; Üstün ve Ersolak, 2020b; Yildirim, Unal ve Surucu, 2013); yedi adet bildiri (Altuntaş, Özalp ve Deniz, 2015; Ceyhan, Batga ve Çavuşoğlu, 2019; Cingöz ve Kaplan, 2015; Demirkasımoğlu ve Arastaman, 2017; Deniz ve Çoban, 2018; Erol, Karakoç ve Aydın, 2018; Köse, İspirli ve Eryılmaz, 2014) ve bir adet kitap bölümü (Koçak, 2019) incelenmiştir. Toplamda otuz yedi (37) çalışma değerlendirme kapsamına alınmıştır.

\section{Verileri Toplama Aracı ve Analiz Yöntemi}

İşyeri nezaketsizliğine ilişkin ulusal ölçekte yapılan araştırmalara ulaşıldıktan sonra, bu araştırmaların özellikleri, mesajları, sonuçları içerik analizi çerçevesinde değerlendirilmiştir. $\mathrm{Bu}$ doğrultuda analizi gerçekleştirebilmek için, ulaşılan araştırmalar genel olarak gözden geçirilmiş ve araştırmaların, yılı, türü, niteliği, kullanılan ölçek, verileri toplama tekniği, kullanılan dil, örneklem grubu, uygulanan analiz teknikleri, bağımlı-bağımsız değişkenler, değişkenler arasındaki korelasyonun yönü kriterleri belirlenmiştir. Bu kriterlere göre elde edilen veriler, hazırlanan 'İşyeri Nezaketsizliğine Yönelik Yapılan Çalışmaları Değerlendirme Formuna' kaydedilmiş ve bu yöntemle otuz yedi (37) araştırma değerlendirilmiştir. Kaydedilen bu veriler tekrar gözden geçirilmiş, frekans dağılımları hesaplanmış, kavrama yönelik olarak sonuçlara varılmaya çalışılmış ve gelecekteki çalışmalara rehberlik edebilecek önerilerde bulunulmuştur.

\section{Araştırmanın Kısıtlı Yönleri}

Araştırmada sadece SOBIAD, YÖK'ün Ulusal Tez Merkezi, Google Scholar ve ULAKBİM Sosyal ve Beşeri Bilimler veri tabanlarından Haziran 2020 tarihi itibariyle ulaşılabilen 'işyeri nezaketsizliği' ile ilgili 
çalışmalar değerlendirilmiştir. Ulaşılamayan çalışmalar, araştırmanın kısıtlı yönünü ifade etmektedir.

\section{Bulgular}

Bu bölümde; işyeri nezaketsizliği kavramı hakkında yapılan araştırmalar, araştırma sorularında belirtilen özelliklere göre değerlendirilmiştir. Araştırmalar; araştırmanın yılı, türü, niteliği, dili, kullanılan ölçek, veri toplama yöntemi, örneklem kitlesi, kullanılan istatistiksel analiz teknikleri, araştırmalardaki bağımlı-bağımsız değişkenler ve korelasyonun yönü kriterlerine göre incelenmiştir. Ulaşllan sonuçlar, Tablo 1,2,3,4,5'de sunulmuştur.

Tablo 1. Araştırmalara Yönelik Bazı Özelliklerin Dağılımı ( $n=37)$

\begin{tabular}{|c|c|c|c|c|c|}
\hline Özellikler & Sayı & Yüzde & Özellikler & Sayı & Yüzde \\
\hline \multicolumn{3}{|c|}{ Araştırmanın Yılı } & \multicolumn{3}{|l|}{ Kullanılan Ölçek } \\
\hline $2010-2013$ & 3 & 8,11 & Cortina vd. (2001) & 20 & 54,04 \\
\hline 2014-2017 & 12 & 32,43 & Cortina vd. (2013) & 3 & 8,11 \\
\hline $2018-2020$ & 22 & 59,46 & Martin ve Hine (2005) & 2 & 5,41 \\
\hline \multicolumn{3}{|c|}{ Araştırmanın Türü } & $\begin{array}{l}\text { Blau ve Andersson } \\
(2005)\end{array}$ & 2 & 5,41 \\
\hline Tez & 13 & 35,14 & Guidroz vd. (2010) & 2 & 5,41 \\
\hline Makale & 16 & 43,24 & $\begin{array}{l}\text { Cortina ve Magley } \\
\text { (2009) }\end{array}$ & 1 & 2,70 \\
\hline Bildiri & 7 & 18,92 & Sliter (2011) & 1 & 2,70 \\
\hline Kitap Bölümü & 1 & 2,70 & \multicolumn{3}{|l|}{ Geliştirilen } \\
\hline \multicolumn{3}{|c|}{ Araştırmanın Niteliği } & Ölçek Kullanılmamış & 2 & 5,41 \\
\hline Görgül & 35 & 94,59 & \multicolumn{3}{|l|}{ Veri Toplama Tekniği } \\
\hline Kavramsal & 2 & 5,41 & Anket & 35 & 94,59 \\
\hline \multicolumn{3}{|c|}{ Araştırmanın Dili } & Kullanılmamış & 2 & 5,41 \\
\hline Türkçe & 31 & 83,78 & Toplam & 37 & 100 \\
\hline İngilizce & 6 & 16,22 & & & \\
\hline
\end{tabular}

İşyeri nezaketsizliği kavramına ilişkin ulaşılan 37 çalışmanın yılı, türü, niteliğii, dili, çalışmada yararlanılan ölçek ve veri toplama tekniğine yönelik bulgular Tablo 1'de gösterilmiştir. Bulgulara göre; araştırmaların yüzde 59,46's1 2018-2020 yılları arasında yapılmıştır. İncelenen araştırmaların yüzde 43,24'ü makalelerden oluşmaktadır. Bu araştırmaların yüzde 94,59'u görgül nitelikte olup, yüzde 83,78'i Türkçe 
olarak yazılmıştır. Ölçek açısından değerlendirildiğinde, araştırmaların yüzde 54,04'ünde Cortina vd. (2001) tarafından geliştirilen işyeri nezaketsizliği ölçeğinden yararlanıldığı saptanmıştır. Çalışmaların yüzde 94,59'unda verilere anket aracılığıyla ulaşıldığı belirlenmiştir.

Tablo 2. Araştırmaların Örneklem Kitlesine Göre Dă̆ılımı (n=35)

\begin{tabular}{lll}
\hline Örneklem & Makale Sayısı & Yüzde(\%) \\
\hline Sağlık Sektörü Çalışanları & 8 & 22,86 \\
Banka Çalışanları & 7 & 20,00 \\
Devlet ve Özel Kurumların Beyaz Yakalı Çalışanları & 4 & 11,43 \\
Farklı Sektör Çalışanları & 4 & 11,43 \\
Akademisyenler & 3 & 8,57 \\
İmalat Sektöründe Çalışanlar & 3 & 8,57 \\
Öğretmenler & 3 & 8,57 \\
İdari Kadro Çalışanları & 2 & 5,71 \\
Sosyal Güvenlik Kurumu Çalışanları & 1 & 2,86 \\
Toplam & 35 & 100,0 \\
\hline
\end{tabular}

Değerlendirme kapsamındaki araştırmalardan ikisi kavramsal nitelikte olduğundan, 35 çalışma üzerinden örneklem kitlesi belirlenmiş ve dağılım Tablo 2'de verilmiştir. Araştırmalarda en çok tercih edilen örneklem kitlesinin; yüzde 22,86 oranında sağlık sektörü çalışanları ve yüzde 20,0 oranında banka çalışanları olduğu saptanmıştır.

Tablo 3. Araştırmalarda Yararlanılan İstatistiksel Analizlerin Dağılımı (n=35)

\begin{tabular}{lll}
\hline Kullanılan Analizler & $\begin{array}{l}\text { Araştırma } \\
\text { Sayısı }\end{array}$ & Yüzde (\%) \\
\hline Güvenilirlik Analizi & 34 & 97,14 \\
Açıllayıcı Faktör Analizi & 10 & 28,57 \\
Açılayııı ve Doğrulayıcı Faktör Analizi & 14 & 40,00 \\
Tanımlayıcı İstatistikler (ortalama, standart sapma, frekans & 31 & 88,57 \\
dağılımı) & & \\
Korelasyon Analizi & 31 & 88,57 \\
Regresyon Analizi (doğrusal, çoklu vb.) & 16 & 45,71 \\
Hiyerarşik Regresyon Analizi & 9 & 25,71 \\
Tek Yönlü Varyans Analizi (Anova) & 8 & 22,86 \\
T- testi & 8 & 22,86 \\
Yapısal Eşitlik Modellemesi & 4 & 11,43 \\
Kruskal Wallis & 3 & 8,57 \\
Scheffe & 2 & 5,71 \\
Mann-Whitney-U & 2 & 5,71 \\
Tukey & 1 & 2,86 \\
\hline
\end{tabular}


Araştırma kapsamındaki 37 çalışmadan 35'i görgül nitelikte olduğu için, bu araştırmalarda kullanılan analizler incelenmiş ve sonuçlar Tablo 3'de gösterilmiştir. Sonuçlara göre; çalışmalarda en yüksek oranlarda kullanılan analiz tekniklerinin, güvenilirlik analizi, tanımlayıcı istatistikler, korelasyon analizi, regresyon analizi ve açıklayıcı-doğrulayıcı faktör analizi olduğu tespit edilmiştir. Araştırmaların tamamında birden fazla istatistiksel analiz yöntemi kullanılmasından dolayı, kodlanan analiz sayısı araştırma sayısından daha fazladır.

Tablo 4. İşyeri Nezaketsizliğinin Bă̆ımsız Değişken Olarak Ele Alındığı Araştırmalarda İliş̧kilendirildiği Bağımlı Değiş̧kenlerin Dağılımı $(n=27)$

\begin{tabular}{|c|c|c|c|c|c|c|c|}
\hline $\begin{array}{l}\text { Bağımlı } \\
\text { Değişkenler }\end{array}$ & $\begin{array}{l}\text { Say1 } \\
\text { (n) }\end{array}$ & $\begin{array}{l}\text { Yüzde } \\
(\%)\end{array}$ & $\begin{array}{l}\text { İlişkinin } \\
\text { Yönü }\end{array}$ & $\begin{array}{l}\text { Bağımlı } \\
\text { Değişkenler }\end{array}$ & $\begin{array}{l}\text { Say1 } \\
\text { (n) }\end{array}$ & $\begin{array}{l}\text { Yüzde } \\
(\%)\end{array}$ & $\begin{array}{l}\text { İlişkinin } \\
\text { Yönü }\end{array}$ \\
\hline İş Doyumu & 9 & 33,33 & - & $\begin{array}{l}\text { Aidiyet, Kontrol } \\
\text { ve Özsaygı } \\
\text { İhtiyacını Tehdit }\end{array}$ & 1 & 3,70 & + \\
\hline $\begin{array}{l}\text { İşten Ayrılma } \\
\text { Niyeti }\end{array}$ & 6 & 22,22 & + & Etik İklim Algısı & 1 & 3,70 & - \\
\hline $\begin{array}{l}\text { İşgören } \\
\text { Performansı }\end{array}$ & 3 & 11,11 & - & $\begin{array}{l}\text { İntikam Alma } \\
\text { İsteği }\end{array}$ & 1 & 3,70 & + \\
\hline Stres Düzeyi & 3 & 11,11 & + & İşe Adanma & 1 & 3,70 & - \\
\hline $\begin{array}{l}\text { Tükenmişlik } \\
\text { (Duygusal } \\
\text { tükenmişlik vs.) }\end{array}$ & 3 & 11,11 & + & $\begin{array}{l}\text { Olumsuz Genel } \\
\text { Sağllk }\end{array}$ & 1 & 3,70 & + \\
\hline $\begin{array}{l}\text { Bilgi Paylaşma } \\
\text { Tutumu }\end{array}$ & 2 & 7,41 & - & Örgütsel Adalet & 1 & 3,70 & - \\
\hline İşyeri Zorbalığı & 2 & 7,41 & + & $\begin{array}{l}\text { Örgütsel } \\
\text { Dişlanma }\end{array}$ & 1 & 3,70 & + \\
\hline Mobbing & 2 & 7,41 & + & $\begin{array}{l}\text { Örgütsel } \\
\text { Sessizlik }\end{array}$ & 1 & 3,70 & + \\
\hline Örgütsel Bağlılık & 2 & 7,41 & - & Örgütsel Güven & 1 & 3,70 & - \\
\hline Örgütsel Sinizm & 2 & 7,41 & + & $\begin{array}{l}\text { Örgütsel } \\
\text { Vatandaşlık } \\
\text { Davranışı }\end{array}$ & 1 & 3,70 & - \\
\hline $\begin{array}{l}\text { Öznel İyi Oluş } \\
\text { Hali }\end{array}$ & 2 & 7,41 & - & $\begin{array}{l}\text { Pozitif Duygu } \\
\text { Durumu }\end{array}$ & 1 & 3,70 & - \\
\hline Psikolojik Sermaye & 2 & 7,41 & - & $\begin{array}{l}\text { Sosyal Destek } \\
\text { Algisı }\end{array}$ & 1 & 3,70 & - \\
\hline $\begin{array}{l}\text { Sosyal Kaytarma } \\
\text { Davranışı }\end{array}$ & 2 & 7,41 & + & Vicdanlılık & 1 & 3,70 & - \\
\hline $\begin{array}{l}\text { Agresyon } \\
\text { Davranışı }\end{array}$ & 1 & 3,70 & + & Yaşam Doyumu & 1 & 3,70 & - \\
\hline
\end{tabular}

İşyeri nezaketsizliğinin bağımsız değişken olarak ele alındığı yirmi yedi (27) araştırmada, ilişkilendirildiği bağımlı değişkenlerin dağılımı 
incelenmiş ve sonuçlar Tablo 4'de gösterilmiştir. Tabloya göre; işyeri nezaketsizliği, yüzde 33,33 oranında iş doyumu, yüzde 22,22 oranında işten ayrılma niyeti, yüzde 11,11 oranlarında iş gören performansı, stres düzeyi ve tükenmişlik ile en yüksek oranlarda ilişkilendirilmiştir. Bağımsız ve bağımlı değişkenler arasındaki korelasyonun yönü, pozitif (+) ve negatif (-) olarak gösterilmiştir. İnceleme sırasında; işyeri nezaketsizliğinin bazı araştırmalarda birden fazla bağımlı değişken ile korelasyonunun değerlendirildiği ve bu nedenle de kodlanan konu sayısının araştırma sayısından fazla olduğu görülmüştür.

Tablo 5. İşyeri Nezaketsizliğinin Bağımlı Değişken Olarak Ele Alındı̆̆ı Araştırmalarda İlişkilendirildiği Bă̆ımsız Değişkenlerin Dă̆ılımı (n=7)

\begin{tabular}{|c|c|c|c|c|c|c|c|}
\hline $\begin{array}{l}\text { Bağımsız } \\
\text { Değişkenler }\end{array}$ & $\begin{array}{l}\text { Say1 } \\
\text { (n) }\end{array}$ & $\begin{array}{l}\text { Yüzde } \\
(\%)\end{array}$ & $\begin{array}{l}\text { İlişkinin } \\
\text { Yönü }\end{array}$ & $\begin{array}{l}\text { Bağımsız } \\
\text { Değişkenler }\end{array}$ & $\begin{array}{l}\text { Say1 } \\
\text { (n) }\end{array}$ & $\begin{array}{l}\text { Yüzde } \\
(\%)\end{array}$ & $\begin{array}{l}\text { İlişkinin } \\
\text { Yönü }\end{array}$ \\
\hline $\begin{array}{l}\text { Makyavelist } \\
\text { Kişilik }\end{array}$ & 2 & 28,57 & + & $\begin{array}{l}\text { Olumsuz } \\
\text { Örgüt İklimi }\end{array}$ & 1 & 14,29 & + \\
\hline $\begin{array}{l}\text { Destekleyici } \\
\text { ve Ilıml } \\
\text { Örgüt İklimi }\end{array}$ & 1 & 14,29 & - & Örgüt Kültürü & 1 & 14,29 & - \\
\hline $\begin{array}{l}\text { İşyerinde } \\
\text { Dışlanma }\end{array}$ & 1 & 14,29 & + & $\begin{array}{l}\text { Örgütsel } \\
\text { Sapma }\end{array}$ & 1 & 14,29 & + \\
\hline $\begin{array}{l}\text { Kaçınmacı } \\
\text { Odakl1lık }\end{array}$ & 1 & 14,29 & + & $\begin{array}{l}\text { Yapisal } \\
\text { Güçlendirme }\end{array}$ & 1 & 14,29 & - \\
\hline $\begin{array}{l}\text { Kötü } \\
\text { Muamele } \\
\text { Algısı }\end{array}$ & 1 & 14,29 & + & $\begin{array}{l}\text { Yönelimci } \\
\text { Odaklılık }\end{array}$ & 1 & 14,29 & - \\
\hline
\end{tabular}

İşyeri nezaketsizliğinin bağımlı değişken olarak ele alındığı yedi (7) araştırmada, ilişkilendirildiği bağımsız değişkenlerin dağılımı incelenmiş ve sonuçlar Tablo 5'de sunulmuştur. Tabloya göre; işyeri nezaketsizliği, en yüksek düzey olan yüzde 28,57 oranında makyavelist kişilik ile ilişkilendirilmiştir. Bağımsız ve bağımlı değişkenler arasındaki korelasyonun yönü, pozitif (+) ve negatif (-) olarak gösterilmiştir. İnceleme sırasında; bağımlı değişken konumundaki işyeri nezaketsizliğinin bazı araştırmalarda birden fazla bağımsız değişken ile korelasyonunun değerlendirildiği ve bu nedenle de kodlanan konu sayısının araştırma sayısından fazla olduğu görülmüştür. Ayrıca, görgül araştırmalardan bir (1) tanesinin ölçek geliştirmeye yönelik olduğu saptanmıştır. 


\section{Tartışma}

Araştırmada, Haziran 2020 tarihine kadar ülkemizde 'işyeri nezaketsizliği' kavramıla ilgili bilimsel dergilerde yayınlanmış olan makaleler, hazırlanmış olan yüksek lisans-doktora tezleri, kongrelerde sunulmuş bildiriler ve kitap bölümleri incelenmiştir. Bu araştırmanın amacı; işyeri nezaketsizliğine yönelik olarak yapılan araştırmaların, yılı, türü, niteliği, kullanılan ölçek, veri toplama tekniği, kullanılan dil, örneklem grubu, yapılan analiz teknikleri, ilişkilendirilen bağımlbağımsız değişkenler ve değişkenler arasındaki korelasyonun yönünü inceleyerek literatüre katkı sağlamaktır. Ulaşılan sonuçlar sırayla verilmiştir.

$\mathrm{Bu}$ çalışmada, öncelikle işyeri nezaketsizliği ile ilgili ulaşılan 37 araştırmanın yıll, türü, niteliği, dili, araştırmada kullanılan ölçek ve veri toplama tekniğine ilişkin bulgular değerlendirilmiştir. Buna göre; araştırmaların yüzde 8,11'i 2010-2013, yüzde 59,46's ise 2018-2020 yılları arasında yapılmıştır. Bu sonuç, işyeri nezaketsizliği konusuna olan ilginin ülkemizde zamanla arttığını ortaya koymakta ve Schilpzand ve arkadaşlarının (2016) bildirimleriyle paralellik göstermektedir. İşyeri nezaketsizliği konusuna duyulan ilginin nedeni, günümüz örgütlerinde nezaketsizliğin artması (Cortina ve arkadaşları, 2001; Gallus ve arkadaşları, 2014) ve bu doğrultuda 'nezaket' kavramına duyulan ihtiyacın bir yansıması olarak düşünülebilir.

İncelenen araştırmaların yüzde 35,14'ü tezlerden, yüzde 43,24'ü makalelerden, yüzde 18,92'si bildirilerden ve yüzde 2,70'si kitap bölümünden oluşmaktadır. Ulaşılan tezlerin sekiz tanesi yüksek lisans beş tanesi de doktora tezidir. İşyeri nezaketsizliğine yönelik çalışmaların her türlü bilimsel platformda yer alması, ulusal ölçekte de konuya önem verildiğinin bir göstergesi olarak görülebilir.

Değerlendirilen araştırmaların yüzde $94,59^{\prime}$ u görgül niteliktedir ve bu görgül araştırmalarda nicel araştırma yöntemi kullanılmıştır. Araştırmaların yüzde 5,41'i kavramsal nitelik taşımaktadır. Ayrıca görgül araştırmaların tamamında veriler anket ile toplanmıştır. Bu sonuçlar, ülkemizde yönetim alanında yapılan bazı araştırmalarla (Arslaner ve Demirci, 2017; Çelik, 2016; Işıkay, 2019; Kutanis vd., 2015; Pekdemir vd., 
2016; Sezgin ve Sönmez, 2018; Yalçınkaya ve Türker, 2016) benzerlik göstermektedir.

Kullanılan dil açısından bakıldığında, çalışmaların Türkçe ve İngilizce dillerinde yazıldığı belirlenmiştir. Araştırmaların büyük çoğunluğunun (yüzde 83,78) Türkçe olarak yazıldığı ve bu sonucun, Pekdemir ve arkadaşlarının (2016) bildirimleriyle farklılık, Çelik (2016)'in bildirimleriyle paralellik gösterdiği saptanmıştır.

Kullanılan ölçek açısından ele alındığında, çalışmaların yarıdan fazlasında (yüzde 54,04) Cortina ve arkadaşları (2001) tarafından geliştirilen ve sonrasında Türkçe'ye uyarlanan işyeri nezaketsizliği ölçeğinin olduğu saptanmıştır. Ölçekler dikkatle incelendiğinde Cortina $(2001,2009,2013)$ 'nın araştırmacı olduğu ölçeklerin daha fazla kullanıldığ ve bu kavramı ortaya koyan ilk araştırmacılardan olduğu tespit edilmiştir. Dikkat çeken bir diğer bulgu ise, araştırmacıların yüzde 10,81'inin var olan ölçeklerden ve literatürden yararlanarak yeni bir ölçek oluşturma çabasıdır. Bu çaba, daha çok Amerika merkezli olarak geliştirilen işyeri nezaketsizliği kavramının ulusal kültüre göre uyumlaştırılabilmesi açısından önemlidir. Ulaşılan sonuçlardan anlaşılacağı üzere, araştırmalarda daha çok yurt dişında geliştirilmiş olan ölçekler kullanılmış ve bu durum bazı araştırmacıların (Işıkay, 2019; Kutanis vd., 2015; Pekdemir vd., 2016) bildirimleriyle benzerlik göstermiştir.

Çalışmalarda en fazla tercih edilen örneklem kitlesinin; sağlık sektörü çalışanları (yüzde 22,86) ve banka çalışanları (yüzde 20,0) olduğu tespit edilmiştir. Bu sonuç, bazı araştırmacıların (Çelik, 2016; Işıkay, 2019; Pekdemir vd., 2016) bildirimleriyle kısmen benzerlik göstermiştir. Örneklem sayılarına bakıldığında ise; en az 101 katılımcının, en fazlada 869 katılımıının araştırma kapsamına alındığı saptanmıştır. Hem evrenin temsil edilmesi açısından hem de işyeri nezaketsizliği kavramının değerlendirilmesi açısından bu sayıların yeterli düzeyde olduğu düşünülmüştür.

Elde edilen bu sonuçlardan sonra, ulaşılan verilerin hangi analiz tekniğine göre incelendiği belirlenmiştir. Sonuçlara göre; araştırmaların tamamına yakınında (yüzde 97,14) güvenilirlik analizi uygulanmış ve işyeri nezaketsizliği ölçeğinin iç tutarlılık katsayısının Cronbach Alfa ile ölçüldüğü belirlenmiştir. Bu sonuç, bazı araştırmacıların (Işıkay, 2019; Kutanis vd., 2015) bildirimleriyle benzerlik göstermektedir. İlaveten, bazı 
çalışmalarda sadece genel işyeri nezaketsizliğinin güvenilirliğine bakıldığı, bazılarında ise yönetici-amir, meslektaş, çalışma arkadaşı, müşteri-hasta gibi alt boyutlar oluşturularak işyeri nezaketsizliğinin değerlendirildiği dolayısıyla bu alt boyutlarında güvenilirliğinin ölçüldüğü saptanmıştır. Ölçülen işyeri nezaketsizliği Cronbach Alfa katsayılarının 0,74 ile 0,99 arasında değiştiği belirlenmiştir. Bu değerler, Kalaycı (2014)'nın sosyal bilimler alanı için bildirdiği 0,60 sınırının üzerindedir ve böylece araştırmaların tamamının güvenilir olduğu kanısına varılmıştır.

Araştırmalarda işyeri nezaketsizliği ölçeğinin geçerliliğini test etmek için, yüzde 28,57 oranında sadece açıklayıcı faktör analizinin uygulandığ 1 ve yüzde 40,0 oranında ise hem açılayıcı hem de doğrulayıcı faktör analizinin uygulandığı ortaya konulmuştur. Her iki faktör analizinin yapılma oranının yıllar içerisinde artış göstermesi, ölçeğin geliştirilmesinde önemli bir adım olarak değerlendirilebilir. Bu sonuç, sadece açıklayıcı faktör analizinin çoğunlukla yapıldığına dikkat çeken bazı araştırmacıların (Iş̧ıay, 2019; Pekdemir vd., 2016) sonuçlarıyla farklılık göstermektedir. Bununla birlikte, en yüksek oranda yararlanılan ilk beş veri analiz tekniğinin; güvenilirlik analizi (yüzde 97,14), tanımlayıcı istatistikler (yüzde 88,57), korelasyon analizi (yüzde 88,57), regresyon analizi (yüzde 45,71) ve açıklayıcı-doğrulayıcı faktör analizi (yüzde 40,0) olduğu tespit edilmiştir. Varılan bu sonuç, bazı araştırmacıların bildirimleriyle (Işıkay, 2019; Pekdemir vd., 2016) benzerlik göstermiştir.

$\mathrm{Bu}$ araştırmada, bağımsız değişken olarak ele alınan işyeri nezaketsizliğinin, hangi bağımlı değişkenlerle korelasyon kurduğu belirlenerek etkilediği ya da etkileme potansiyeli olduğu kavramlar saptanmaya çalışılmıştır. İşyeri nezaketsizliğinin ilişkilendirildiği bu bağımlı değişkenlerin; iş doyumu, işten ayrılma niyeti, işgören performans1, stres düzeyi, tükenmişlik, bilgi paylaşma tutumu, işyeri zorbalığı, mobbing, örgütsel bağlılık, örgütsel sinizm, öznel iyi oluş hali, psikolojik sermaye, sosyal kaytarma davranışı, agresyon davranışı, aidiyet, kontrol ve özsaygı ihtiyacını tehdit, etik iklim algısı, intikam alma isteği, işe adanma, olumsuz genel sağlık, örgütsel adalet, örgütsel dışlanma, örgütsel sessizlik, örgütsel güven, örgütsel vatandaşlık davranışı, pozitif duygu durumu, sosyal destek algısı, vicdanlılık ve 
yaşam doyumu olduğu tespit edilmiştir. Bu bağımlı değişkenler arasında en yüksek oranda işyeri nezaketsizliğiyle ilişkilendirilen kavramların, iş doyumu, işten ayrılma niyeti, işgören performansı, stres düzeyi ve tükenmişlik olduğu belirlenmiştir. Diğer taraftan bağımlı değişken olarak ele alınan işyeri nezaketsizliğinin, hangi bağımsız değişkenlerle korelasyon kurduğu belirlenerek nezaketsizliği etkileyebilecek değişkenler saptanmaya çalışılmıştır. İşyeri nezaketsizliğinin ilişkilendirildiği bu bağımsız değişkenlerin; makyavelist kişilik, destekleyici ve ılımlı örgüt iklimi, işyerinde dışlanma, kaçınmacı odaklılık, kötü muamele algısı, olumsuz örgüt iklimi, örgüt kültürü, örgütsel sapma, yapısal güçlendirme ve yönelimci odaklılık olduğu tespit edilmiştir. Bu bağımsız değişkenler arasında en yüksek oranda işyeri nezaketsizliğiyle ilişkilendirilen kavramın makyavelist kişilik olduğu bulgulanmıştır.

İşyeri nezaketsizliği ile ilişkilendirilen kavramlar belirlendikten sonra, değişkenler arasındaki korelasyonun hangi yönde olduğu ve uluslararası literatürdeki diğer araştırmalarla olan benzerlik durumu üzerinde karşılaştırmalar yapılmıştır. Buna göre işyeri nezaketsizliği ile; iş doyumu (Welbourne vd., 2015, s.211), işgören performans1 (Logan, 2016, s.50), bilgi paylaşma tutumu (Porath ve Pearson, 2010, s.69), örgütsel bağlllık (Spence Laschinger vd., 2009, s.306), destekleyici ve 1lımlı örgüt iklimi, etik iklim alg1sı (Felblinger, 2008, s.234), örgütsel adalet (Lim ve Lee, 2011, s.101; Pearson vd., 2000, s.130), örgütsel güven (Logan, 2016, s.50), pozitif duygu durumu (Pearson vd., 2000, s.130), sosyal destek algıs1 (Miner vd., 2012, s.346), yaşam doyumu (Miner ve arkadaşları, 2012, s.346), örgüt kültürü (Pearson ve Porath, 2005, s.8), örgütsel vatandaşlık davranışı (Porath ve Erez, 2009, s.29), işe adanma (Guo, Qiu ve Gan, 2020, s.7), psikolojik sermaye (Shabir vd., 2014, s.10), vicdanlılık, öznel iyi oluş hali, yapısal güçlendirme ve yönelimci odaklılık arasında olumsuz yönde anlamlı bir korelasyon olduğu ve bu bulgunun belirtilen uluslararası çalışmalarla benzerlik gösterdiği saptanmıştır. Diğer taraftan işyeri nezaketsizliği ile; işten ayrılma niyeti (Huang ve Lin, 2019, s.49), stres düzeyi (Dion, 2006, s.89; Lim vd., 2008, s.100), tükenmişlik (Oyeleye vd., 2013, s.540), işyeri zorbalığı, mobbing, agresyon davranışı (Andersson ve Pearson, 1999, s.462; Dion, 2006, s.32), intikam alma isteği (Porath ve Pearson, 2010, s.69), olumsuz genel sağlık (Hershcovis, 2011, s.508), kötü muamele algıs1 
(Pearson vd., 2000, s.130), olumsuz örgüt iklimi (Taylor, 2010, s.51), örgütsel sapma (Andersson ve Pearson,1999, s.456), örgütsel dişlanma (Mahfooz vd.,2017, s.408), örgütsel sinizm (Manzoor, Manzoor ve Khan, 2020, s.95), örgütsel sessizlik, makyavelist kişilik, kaçınmacı odaklılık, aidiyet, kontrol ve özsaygı ihtiyacını tehdit, sosyal kaytarma davranışı arasında olumlu yönde anlamlı bir korelasyon olduğu ve bu korelasyonun vurgulanan çalışmalarla benzerlik gösterdiği ortaya konulmuştur.

İncelenen araştırmalarda işyeri nezaketsizliği ile ilişkilendirilen diğer bir değişkenin sosyo-demografik değişkenler olduğu dikkat çekmektedir. Bu değişkenler arasında; yaş, cinsiyet, eğitim, gelir, çalışma yılı, mevcut kurumda çalışma yılı ve çalışma pozisyonu olduğu görülmüştür. Yaş faktörü dikkate alınarak yapılan bazı araştırmalarda (Akcakavaklı, 2019; Bolat, 2018), yaşı diğer gruplara göre daha fazla olan çalışanların nezaketsizlik yaşama düzeylerinin daha düşük olduğu saptanmıştır. Ulaşılan bu sonucun, bazı araştırmalarla (Pearson vd., 2000, s.127; Pearson ve Porath, 2005, s.10) paralellik gösterdiği belirlenmiştir. Yapılan bir araştırmada (Ceyhan, Batga ve Çavuşoğlu, 2019), erkeklerin işyeri nezaketsizliği algısının daha yüksek olduğu belirlenmiştir. Diğer bir araştırmada ise (Akcakavaklı, 2019), kadınların nezaketsizlik ortalaması erkeklerden anlamlı olarak daha yüksek bulunmuştur. Bir başka araştırmada ise (Demirkasımoğlu ve Arastaman, 2017), kadınların erkeklere göre daha fazla nezaketsizliğin hedefinde olduğu ancak, her iki grubunda işyeri nezaketsizliğiyle karşı karşıya kaldığı tespit edilmiştir. Varılan bu sonuçların Cortina ve arkadaşlarının (2001, s.64) bildirimleriyle benzerlik gösterdiği saptanmıştır. İlaveten Demirkasımoğlu ve Arastaman (2017), nezaketsiz davranışları en çok erkeklerin sergilediğini belirlemiş ve bu durum bazı araştırmacıların (Pearson vd., 2000; Reio ve Ghosh, 2009) bildirimleriyle paralellik göstermiştir. Eğitim açısından bakıldığında, yüksek lisans mezunlarının nezaketsizlik algı ortalamasının lise mezunlarından daha yüksek olduğu saptanmıştır (Akcakavaklı, 2019; Ceyhan, Batga ve Çavuşoğlu, 2019). Bu durumun, eğitim seviyesi yükseldikçe nezaket kuralları ve nezaketsiz davranışlar üzerine bireyde var olan bilinç düzeyinin gelişmesinden ileri gelebileceği düşünüldü. Gelir durumu yüksek olan grubun diğer düşük gruplara göre nezaketsizliğe maruz kalma düzeyinin daha düşük olduğu belirlenmiştir 
(İlgın, 2019). Cortina ve arkadaşları (2001, s.75), daha güçlü pozisyonlarda olan prestij sahibi bireylerin daha yüksek düzeyde nezaketsiz davrandığını tespit etmiştir. Diğer taraftan, çalışma yılı diğer gruplara göre daha fazla olan çalışanların nezaketsizlik puan ortalamasının daha düşük olduğu ortaya konulmuştur (Akcakavaklı, 2019; Ceyhan, Batga ve Çavuşoğlu, 2019). Mevcut kurumunda çalışma yılı diğer gruplara göre daha fazla olan çalışanların da nezaketsiz durumlarla karşılaşma düzeyinin daha düşük olduğu belirlenmiştir (Akcakavaklı, 2019). Ulaşılan bu sonuçlar, bazı araştırmacıların (Pearson vd., 2000; Pearson ve Porath, 2005) sonuçlarıyla paralellik göstermektedir. Ayrıca, çalışma pozisyonu daha yüksek düzeyde olan çalışanların, daha düşük olan çalışanlara göre daha az nezaketsizliğe maruz kaldıkları saptanmıştır (Bolat, 2018). Bu sonuç, Pearson ve arkadaşlarının (2000) bildirimleriyle benzerlik göstermektedir.

Üzerinde durulan bir diğer durum ise, işyeri nezaketsizliğinin ne sıklıkla gerçekleştiğidir. Küçük ve Çakıcı (2018a), katılımcıların yüzde 67'inin çalışma hayatı boyunca en az bir kere nezaketsizliğe maruz kaldığını tespit etmiştir. Bu değer, bazı araştırmacıların (Cortina vd. 2001; Gallus vd., 2014) bildirimlerinden düşük bulunmuştur. Aynı araştırmada çalışanların son altı ay içerisinde en fazla yöneticilerinden (yüzde 41) ve iş arkadaşlarından (yüzde 40) kaynaklı nezaketsizliğe maruz kaldığı saptanmiştır.

Değerlendirme kapsamındaki yirmi sekiz (28) araştırmada nezaketsizlik ortalaması verilmiş, bir (1) tanesinde 6'lı likert (puanlama: 1-6) diğerlerinde 5'li likert ölçeği kullanılmıştır. Kullanılan 5'li likert ölçeklerinin 2'sinde puanlama 0-4 aralığında $25^{\prime}$ inde ise 1-5 aralığında yapılmıştır. Bu araştırmaların 25'inde işyeri nezaketsizliği ortalaması 3 'ün altında diğerlerinde ise üzerindedir. Buradan yola çıkarak örgütlerde işyeri nezaketsizliğinin genel olarak düşük düzeyde seyrettiği, çalışanların birbirlerine nazik davranmaya çalıştıkları ancak zaman zaman nezaketsiz davranışlara maruz kalındığı sonucuna varılmıştır. Bireysel (statü, stres vb.) ve örgütsel (iş yükü, yöneticiler vb.) birçok faktörün işyeri nezaketsizliğine neden olduğu dikkate alındığında, örgütlerde nezaketsizliği tamamen ortadan kaldırmanın mümkün olmadığı açıktır. Burada önemli olan nezaketsiz davranışların tepe noktasını (Andersson ve Pearson, 1999, s.462) aşarak hedefe zarar veren 
saldırganlık davranışlarına dönüşmesini engellemektir. Bilindiği üzere (Pearson vd., 2000) işyeri nezaketsizliği çalışanın arkadaşları, eşi ve tanık olanlar aracılığıyla diğer kurumlara da yayılabilmekte ve zamanla ülke genelinde nezaketsizlik kültürünün yerleşmesine neden olabilmektedir.

İncelenen araştırmalarda, çalışanların hangi bireylerden ne düzeyde nezaketsizlik gördükleri de saptanmıştır. Çalışanların; yöneticilerden, meslektaş/çalışma arkadaşlarından, hizmet sundukları bireylerden kaynaklı nezaketsiz davranışlarla karşılaştıkları belirlenmiş ve farklılıklar ortaya konulmuştur. Bazı araştırmalara göre; yöneticiden görülen nezaketsizliğin, meslektaş/çalışma arkadaşı nezaketsizliğinden daha düşük olduğu (Baran, 2019; Işıkay, 2018; Keçeci, 2017; Kızıloğlu, 2019), bazılarında ise daha yüksek olduğu (Bayrakci, 2019; Erdaş, 2016; Küçük ve Çakıcı, 2018a; Küçük ve Çakıcı, 2018b) tespit edilmiştir. Bu sonuç; çalışanların en az yöneticilerden en fazla meslektaşlarından nezaketsizlik gördüklerini belirten bazı araştırmalarla (Spence Laschinger, 2014, s.287; Spence Laschinger vd., 2009, s.306) kismen uyumluluk göstermektedir. Ayrıca, maruz kalınan nezaketsizlik durumunun düşük düzeyli olduğu ve Spence Laschinger ve arkadaşlarının (2009, s.306) bildirimleriyle paralellik gösterdiği saptanmıştır.

Dikkat çeken bir diğer konu, bireysel olarak nezaketsizliğe karşı nasıl davranışlar gösterildiği konusudur. Demirkasımoğlu ve Arastaman (2017), nezaketsizliğe karşı en sıklıkla verilen tepkilerin; 'yöneticiye anlatmak, nezaketini korumak, mecbur kalmadıkça iletişim kurmamak, suçu kendinde aramak ve nezaketsiz bireyi bir daha tekrarlamaması konusunda tehdit etmek' olduğunu bildirmiştir. İlaveten daha az sıklıkla verilen tepkilerin ise; 'yazılı olarak şikayette bulunmak, aynı şekilde nezaketsizlikle yanıt vermek, nezaketsiz kişinin kötü şeyler yaşamasını dilemek ve işinde gösterdiği çabayı azaltmak' olduğu saptanmıştır. Bu konu hakkında uluslararası düzeyde araştırmalar (Beattie ve Griffin, 2014, s.633; Pearson vd., 2000, s.130) yapıldı̆̆1 da görülmüştür. Pearson ve arkadaşları (2000, s.130), nezaketsizliğin hedefinde olan bireylerin koridorlarda faille karşılaşmamak için eski yollarını değiştirdiğini, ortak faaliyetlere katılmadığını ve işte ortaya koydukları çabayı azalttığını belirlemiştir. Beattie ve Griffin (2014, s.633), nezaketsizlikle karşılaşan bireylerin verdikleri tepkilerin; kışkırtıcıyı görmezden gelmek ya da ondan kaçınmak, kışkırtıcıya olumsuz cevap vermek, en az bir kez 
affetmek, başka birilerinden destek istemek ve kışkırtıcı dışındaki birine olumsuz tepki vermek olduğunu bildirmiştir. Demirkasımoğlu ve Arastaman (2017)'ın bildirimlerinin, belirtilen yurt dışındaki araştırma bulgularıyla benzerlik gösterdiği belirlenmiştir.

Ele alınan bir diğer husus, işyeri nezaketsizliğinin önlenmesidir. Demirkasımoğlu ve Arastaman (2017), 'çalışanlara yönelik olarak nezaket kuralları, öfke ve stres yönetimi gibi bireysel gelişim konularında hizmet içi eğitimler düzenlemek, nazik kişileri işe almak, kurumda kişiler arası ilişkilere yönelik düzenleyici kurallar geliştirmek, nezaketsiz davranan bireyleri işten uzaklaştırmak' gibi yaklaşımların nezaketsizliği önlemede etkili olabileceğini bildirmiştir. Vurgulanan bu mücadele yöntemlerinin, bazı araştırmacıların (Pearson vd., 2000, s.134; Pearson ve Porath, 2005, s.13; Porath ve Pearson, 2010, s.67; Porath ve Pearson, 2013, s.118-119) bildirimleriyle benzerlik gösterdiği saptanmıştır.

\section{Sonuç ve Öneriler}

Sonuç olarak; işyeri nezaketsizliği hakkında yapılan araştırmaların yıllar içerisinde arttığı, her türlü bilimsel çalışmada bu konuya yer verildiği, nicel araştırmaların ağırlıklı olduğu, en fazla oranda sağlık çalışanlarına yönelik araştırmalar yapıldığı, çoğunlukla yurt dışı kaynaklı ölçeklerin kullanılmasının yanında yazarlarca geliştirilen ölçeklerde olduğu, ölçeklerin geçerlilik çalışmalarına önem verildiği saptanmıştır. Bununla birlikte işyeri nezaketsizliğine maruz kalan çalışanlarda iş doyumunun azaldığı ve işten ayrılma niyetinin arttığı belirlenmiştir. Özellikle makyavelist kişilik özelliğine sahip bireylerin, nezaketsiz bir ortamın oluşmasında etkili olduğu belirlenmiştir. Varılan bu sonuçlar doğrultusunda aşağıdaki önerilerde bulunulmuştur:

- Nicel araştırmaların yanında karma ve nitel araştırmalara da yer verilebilir.

- Bireylerin nezaketsiz davranışlara maruz kalma ve nezaketsiz davranış sergileme durumları ayrı ayrı ele alınabilir.

- Çalışılan sektöre göre sergilenen nezaketsiz davranışların farklılık gösterme durumu incelenebilir. 
- Bireyin nezaketsizlik gördüğü üstünden, meslektaşından ve astından ne ölçüde etkilendiği, ne tür tepkiler verdiği, bu gibi faktörlerin farklılaşma durumu belirlenebilir.

- Liderlik, yönetim şekli, örgütsel destek, işe yabancılaşma, iş-aile çatışması gibi daha az çalışılmış konularla nezaketsizlik arasındaki ilişkiler değerlendirilebilir.

- Bireysel ve örgütsel mücadele yöntemleri ulusal değerler göz önünde bulundurularak geliştirilip, etkinliği değerlendirilebilir. 


\section{EXTENDED ABSTRACT}

\section{Workplace Incivility: A Content Analysis on National Literature \\ * \\ Çağdaş Işıkay - Soner Taslak \\ Muğla Sıtkı Koçman University}

Workplace incivility is verbal-nonverbal, passive, implied, indirect, lowintensity behaviors that violate the accepted norms of respect in the workplace, cause the development of feelings and thoughts that the individual is disrespected, and can be upsetting and hurtful. It may be important for our country to determine why workplace incivility arises among employees, in which direction it develops, what effects it has, and the solution proposals developed by organizations.

The aim of the study is to examine the studies on workplace incivility in terms of features such as year, type, quality, scale used, data collection technique, language used, sample group, analysis techniques, related dependent-independent variables, the direction of the correlation between variables, and in this way to contribute to the literature.

In the research, thirty-seven studies consisting of articles published in scientific journals, master's-doctorate theses, papers presented in congresses and book chapters on the concept of 'workplace incivility' until June 2020 in our country were examined. The data obtained according to the determined criteria were recorded in the prepared evaluation form. These recorded data were reviewed again, their frequency distributions were calculated, and it was tried to reach conclusions regarding the concept. In this study, content analysis, which is one of the qualitative research methods, was used.

As a result; 59.46 percent of the studies were conducted between 2018 and 2020. 43.24 percent of the reviewed studies consist of articles. Of these studies, 94.59 percent were empirical and 83.78 percent were written in Turkish. When evaluated in terms of scale, it was determined that the workplace incivility scale developed by Cortina et al (2001) was used in 54.04 percent of the studies. In 94.59 percent of the studies, it was determined that the data were collected through questionnaires. It has 
been determined that the most preferred sample group in the studies are health sector employees (22.86\%) and bank employees (20.0\%).

In this study, it was determined that the analysis techniques used at the highest rates were reliability analysis, descriptive statistics, correlation analysis, regression analysis and explanatory-confirmatory factor analysis. Reliability analysis was applied in almost all of the studies (97.14 percent), and it was determined that the internal consistency coefficient of the workplace incivility scale was measured with Cronbach Alpha. In addition, in order to test the validity of the workplace incivility scale, it was revealed that only explanatory factor analysis was performed at a rate of 28.57 percent and both explanatory and confirmatory factor analysis was performed at a rate of 40.0 percent.

In the research, with workplace incivility; job satisfaction, employee performance, knowledge sharing attitude, organizational commitment, supportive and moderate organizational climate, ethical climate perception, organizational justice, organizational trust, positive mood, perception of social support, life satisfaction, organizational culture, organizational citizenship behavior, work dedication, psychological capital, conscientiousness, subjective well-being and structural empowerment between it was determined that there is a significant negative correlation. On the other hand, with workplace incivility; intention to leave, stress level, burnout, workplace bullying, mobbing, aggressive behavior, desire to take revenge, negative general health, maltreatment perception, negative organizational climate, organizational deviation, organizational exclusion, organizational cynicism, organizational silence, machiavellian personality, avoidant orientation, social loafing behavior, the need for belonging, control and self-esteem threat between it was found that there was a positive significant correlation.

Another consideration is how often workplace incivility occurs. Küçük and Çakıcı (2018a) found that 67 percent of the participants were exposed to incivility at least once during their working life. In the same study, it was determined that employees were exposed to incivility mostly from their managers (41 percent) and colleagues (40 percent) in the last six months. 
In the study, it was concluded that workplace incivility is generally low in organizations, employees try to be kind to each other, but from time to time, they are exposed to incivility. Considering that many factors such as individual (status, stress, etc.) and organizational (workload, managers, etc.) cause workplace incivility, it is clear that it is not possible to completely eliminate incivility in organizations. The important thing here is to prevent the incivility behaviors from turning into aggressive behaviors that harm the target by exceeding the peak (Andersson \& Pearson, 1999, p.462). As is known (Pearson et al., 2000), workplace incivility can spread to other institutions through the employee's friends, spouse and witnesses, and over time, it can cause a culture of incivility to settle throughout the country.

Another issue that draws attention is how individuals behave towards incivility. Demirkasımoğlu and Arastaman (2017) state that the most frequent reactions to incivility are; He stated that 'to tell the manager, to maintain his courtesy, not to communicate unless necessary, to blame himself, and to threaten the rude individual not to repeat it again'. In addition, less frequent responses are; It was determined that 'to make a complaint in writing, to respond in the same way with impoliteness, to wish bad things to the rude person and to reduce the effort he made in his job'.

In line with these results, the following recommendations were made:

- In addition to quantitative research, mixed and qualitative research can also be included.

- Exposure to incivility and display of incivility can be handled separately.

- The difference between the incivility behaviors exhibited according to the sector can be examined.

- The extent to which the individual is affected by his superior, colleague and subordinate, what kind of reactions he gives, and the differentiation status of such factors can be determined.

- Relationships between less studied subjects such as leadership, management style, organizational support, work alienation, work-family conflict and incivility can be evaluated. 
- Individual and organizational struggle methods can be developed by takinginto account national values and their effectiveness can be evaluated.

\section{Kaynakça / References}

Akcakavaklı, H. (2019). İsyeri nezaketsizliği ile stres arasındaki ilişkide psikolojik sermayenin rolü. Yüksek Lisans Tezi. Marmara Üniversitesi, İstanbul.

Altuntaş, G., Özalp, B. ve Deniz, N. (2015). Örgüt kültürünün sosyal kaytarma davranışına etkisinde işyeri nezaketsizliğinin rolü, 23. Ulusal Yönetim ve Organizasyon Kongresi, 505-512, 14-16 Mayıs, MUĞLA.

Andersson, L.M. ve Pearson, C. M. (1999). Tit for tat? The spiraling effect of incivility in the workplace. Academy of Management Review, 24(3), 452471.

Arslaner, E. ve Demirci, B. (2017). Presenteeism: Literatüre bakış ve içerik analizi. 7th International Conference of Strategic Research on Social Science and Education, 267-274.

Baran, H. (2019). İşyeri nezaketsizliğinin işe adanmaya etkisinde psikolojik sermayenin rolü. Doktora Tezi. Kütahya Dumlupınar Üniversitesi, Kütahya.

Batga, B. ve Ceyhan, S. (2019). İşyeri nezaketsizliğinin çalışanlar üzerindeki etkisi: Banka çalışanları üzerine bir araştırma. Çukurova Araştırmaları, 5(2), 250-262.

Bayrakci, C. (2019). İşyeri nezaketsizliği ile iş stresi arasındaki ilişki: Akademisyenler üzerine bir araştırma. Yüksek Lisans Tezi. Kafkas Üniversitesi, Kars.

Beattie, L. ve Griffin, B. (2014). Accounting for within-person differences in how people respond to daily incivility at work. Journal of Occupational and Organizational Psychology, 87(3), 625-644.

Bolat, Ezgi (2018). Hemşirelikte Nezaketsizlik Ölçeği'nin Türkçe geçerlik ve güvenirlik çalışması. Yüksek Lisans Tezi. Manisa Celal Bayar Üniversitesi, Manisa.

Ceyhan, S., Batga, B. ve Çavuşoğlu, S. (2019). Hizmet sektöründe çalışanların işyeri nezaketsizliğine yönelik algılarının demografik özelliklere göre analizi: Bingöl ilinde bir alan çalışması. International Black Sea Coastline Countries Symposıum, 269-282, May 2-5, Batumi / Georgıa. 
Cingöz, A. ve Kaplan, A. (2015). The effect of workplace incivility on job satisfaction and organizational trust: A study of industrial enterprises in Turkey. 12-15, The 2015 WEI International Academic Conference Proceedings Vienna, Austria

Cortina, L. M., Magley, V. J., Williams, J. H. ve Langhout, R. D. (2001). Incivility in the workplace: Incidence and impact. Journal of Occupational Health Psychology, 6(1), 64-80.

Çelik, N. (2016). Yenilikçilik konusunda yapılan doktora tezlerinin içerik analizi yöntemiyle değerlendirilmesi. Uluslararası Ekonomi ve Yenilik Dergisi, 2(1), 29-42.

Delen, M. G. (2010). Çalışma hayatında işyeri kabalığı olgusu. İstanbul Üniversitesi İktisat Fakültesi. Maliye Araştırma Merkezi Konferansları, 53,43-58.

Demirkasımoğlu, N. ve Arastaman, G. (2017). Öğretmenlerin okulda nezaketsizlik olgusuna ilişkin görüşleri. Manisa Celal Bayar Üniversitesi Sosyal Bilimler Dergisi, 15(1), 167-188.

Demirsel, M. T. ve Erat, L. (2019). Algılanan işyeri nezaketsizliğinin çalışan memnuniyeti üzerindeki etkisi. Selçuk Üniversitesi Sosyal Bilimler Enstitüsü Dergisi, Prof. Dr. Fuat Sezgin Özel Sayısı, 209-221.

Deniz, M. ve Çoban, R. (2018). Çalışanların işyeri nezaketsizliği ve örgütsel sinizm algıları arasındaki ilişkileri belirlemeye yönelik imalat sektörü üzerinde bir araştırma. 6. Örgütsel Davranış Kongresi Bildiriler Kitabı, 343-354, 2-3 Kasim Isparta.

Dion, M. J. (2006). The impact of workplace incivility and occupational stress on the job satisfaction and turnover intention of acute care nurses. Doctoral Dissertation. ETD Collection for University of Connecticut, Storrs.

Erdaş, K. D. (2016). Workplace incivility in the context of honor culture. Doctoral Thesis. Sabancı University, İstanbul.

Erol, Y., Karakoç, G.A. ve Aydın, N.C. (2018). İş yeri zorbalığı ve iş yeri nezaketsizliğinin algılanan stres üzerine etkisi: Sağlık kurumlarında bir araştırma, 2nd International EMI Entrepreneurship \& Social Sciences Congress, 968-979, 09-11 November, Cappadocia.

Felblinger, D. M. (2009). Incivility and bullying in the workplace and nurses'shame responses. Journal of Obstetric, Gynecologic and Neonatal Nursing, 37(2), 234-242. 
Gallus, J. A., Bunk, J. A., Matthews, R. A., Barnes-Farrell, J. L., ve Magley, V. J. (2014). An eye for an eye? Exploring the relationship between workplace incivility experiences and perpetration. Journal of Occupational Health Psychology, 19(2), 143-154.

Gök, S., Karatuna, I. ve Başol, O. (2019). İşyeri Nezaketsizliği Ölçeği'nin Türkçe'ye uyarlanması. Türk Psikoloji Yazlları, 22(44), 106-115.

Göktepe, E. A. ve Keleş, D. (2019). İşyeri nezaketsizliği ve işten ayrılma eğilimi ilişkisi; akademik personel üzerine bir araştırma. Sosyal Araştırmalar ve Davranış Bilimleri Dergisi, 5(8), 262-273.

Guo, J., Qiu, Y. ve Gan, Y. (2020). Workplace incivility and work engagement: The chain mediating effects of perceived insider status, affective organizational commitment and organizational identification. Current Psychology, Springer, 1-12.

Gültaç, A. S. (2019). Örgütsel sapma ve nezaketsizlik davranışları ilişkisinde işyerinde dışlanmanın aracı rolü: Să̆llk kurumlarında bir araştırma. Yüksek Lisans Tezi. Hacettepe Üniversitesi, Ankara.

Güzel, C. (2019). The mediating effect of organizational commitment and job satisfaction in the relationship between workplace incivility and turnover intention, Master Thesis. Middle East Technical University, Ankara.

Hershcovis, M. S. (2011). Incivility, social undermining, bullying...oh my! A call to reconcile constructs within workplace aggression research. Journal of Organizational Behavior, 32, 499-519.

Huang, H. T. ve Lin, C.P. (2019). Assessing ethical efficacy, workplace incivility and turnover intention: A moderated-mediation model. Review of Managerial Science, 13(1), 33-56.

Hüner, B. B. (2019). Customer incivility and turnover intention of bank employees: The moderating role of perceived organizational support and big five personality traits. Master Thesis. Middle East Technical University, Ankara.

Ismail, I. R. (2011). Effect of workplace incivility on coworker helping: The mediating role of hurt feelings. Universiti Tun Abdul Razak e-Journal, $7(2), 11-22$.

Işıkay, Ç. (2018). İsyeri nezaketsizliği, tükenmişlik ve iş doyumu ilişkisinde örgütsel adalet algisının aracilık rolü: Muğla ili kamu hastaneleri birliğinde görev yapan hemşireler üzerine bir araştırma. Doktora Tezi. Muğla Sitkı Koçman Üniversitesi, Muğla. 
Işıkay, Ç. (2019). Yıkıcı örgütsel sapma: Bir literatür değerlendirmesi. International Social Sciences Studies Journal, 5(50), 6623-6634.

İlgın, C. (2019). İşyeri nezaketsizliği ile sinizm arasındaki ilişkide öznel iyi oluş halinin rolü. Yüksek Lisans Tezi. Marmara Üniversitesi, İstanbul.

Kalaycı, Ş. (2014). SPSS uygulamalı çok değişkenli istatistik teknikleri. Ankara: Asil Yayın.

Kanten, P. (2014). İşyeri nezaketsizliğinin sosyal kaytarma davranışı ve işten ayrılma niyeti üzerindeki etkisinde duygusal tükenmenin aracılık rolü. Aksaray Üniversitesi İktisadi ve İdari Bilimler Fakültesi Dergisi, 6(1), 11-26.

Kaya, E. Ü. (2015). İşyeri kabalığı, örgütsel bağlılık, örgütsel özdeşleşme ve iş tatmin değişkenleri arasındaki ilişkiler ve birbirleri üzerindeki etkileri: Yüksek öğretimde bir çalışma. The Journal of Academic Social Science Studies, 41, 55-78.

Keçeci, M. (2017). The role of supervisor and coworker incivility on intention to share knowledge and satisfaction: The moderating effect of conscientiousness and the mediating effect of desire for revenge. Doktora Tezi. Marmara Üniversitesi, İstanbul.

Khadjehturian, R. (2012). Stopping the culture of workplace incivility in nursing. Clinical Journal of Oncology Nursing,16(6), 638-639.

Kızıloğlu, E. (2019). İşyeri nezaketsizliğinin bilgi paylaşma tutumu ve iş çıktıları üzerindeki etkisi: Algılanan etik iklimin aracı rolü. Doktora Tezi. Selçuk Üniversitesi, Konya.

Koçak, D. (2019). İşyeri nezaketsizliğinin örgütsel vatandaşlık davranışı üzerindeki etkisi: Üretim sektöründe bir araştırma. İ. Elagöz, G. Erdoğan, A. Gezer ve A. Yılmaz (Ed.). Sosyal Bilimler Alanında Araştırma Makaleleri-1 içinde (ss. 322 -340). Ankara: Gece Kitaplığı.

Köse, S., İspirli, D. ve Eryılmaz, İ. (2014). Düzenleyici odaklar ve işyeri nezaketsizliği ilişkisinde örgütsel iklimin düzenleyici etkisi: Keşfedici bir araştırma, 2. Örgütsel Davranış Kongresi, 241-249, 7-8 Kasım, Kayseri.

Kumral, T. (2017). İşyeri nezaketsizliği ve örgütsel sessizlik ilişkisinde örgütsel dışlanmanın aracı rolü. Yüksek Lisans Tezi. Marmara Üniversitesi, İstanbul.

Kumral, T. ve Çetin, C. (2016). İşyeri nezaketsizliği üzerine bir yazın incelemesi. Kafkas Üniversitesi Sosyal Bilimler Enstitüsü Dergisi, Sonbahar, Ek Sayı 1, 153-171. 
Kutanis, R.Ö., Özsoy, E., Karakiraz, A., Aras, M., Erol, E. ve Uslu, O. (2015). Örgüt kültürü çalışmalarının yöntem ve kapsam bakımından incelenmesi: Lisansüstü tezler üzerinden bir inceleme. Yönetim ve Ekonomi Araştırmaları Dergisi, 13(1), 123-141.

Kutlu, A. ve Bilgin, N. (2017). İşyeri nezaketsizlik ölçeğinin hemşireler üzerinde Türkçe geçerlik ve güvenirliği çalışması. Sağlık ve hemşirelik yönetimi dergisi, 2(4), 56-62.

Küçük, Ö. ve Çakıcı, A. (2018a). İşyeri kabalığının öznel iyi oluş haline etkisi. İş ve İnsan Dergisi, 5(1), 75-87.

Küçük, Ö. ve Çakıcı, A. (2018b). İşyeri kabalığının çalışan performansına etkisi. Balıkesir Üniversitesi Sosyal Bilimler Enstitüsü Dergisi, 21(39), 365385.

Lim, S., Cortina, L. M. ve Magley, V. J. (2008). Personal and workgroup incivility: Impact on work and health outcomes. Journal of Applied Psychology, 93(1), 95-107.

Lim, S. ve Lee, A. (2011). Work and nonwork outcomes of workplace incivility: Does family support help? Journal of Occupational Health Psychology, 16(1), 95-111.

Logan, T. R. (2016). Influence of teamwork behaviours on workplace incivility as it applies to nurses. Creighton Journal of Interdisciplinary Leadership, 2(1), 47-53.

Mahfooz, Z., Arshad, A., Nisar, Q. A., Ikram, M. ve Azeem, M. (2017). Does workplace incivility and workplace ostracism influence the employees' turnover intentions? Mediating role of burnout and job stress and moderating role of psychological capital. International Journal of Academic Research in Business and Social Sciences, 7(8), 398413.

Manzoor, M.T., Manzoor, T. ve Khan, M. (2020). Workplace incivility: A cynicism booster leading to turnover intentions, Decision, 47(1), 91-99.

Miner, K. N., Settles, I. H., Pratt-Hyatt, J. S. ve Brady, C. C. (2012). Experiencing incivility in organizations: The buffering effects of emotional and organizational support. Journal of Applied Social Psychology, 42(2), 340-372.

Oyeleye, O., Hanson, P., O'connor, N. ve Dunn, D. (2013). Relationship of workplace incivility, stress, and burnout on nurses' turnover intentions and psychological empowerment. The Journal of Nursing Administration, 43(10), 536-542. 
Pearson, C. M., Andersson, L. M. ve Porath, C. L. (2000). Assessing and attacking workplace incivility. Organizational Dynamics, 29(2), 123137.

Pearson, C. M., Andersson, L. M. ve Wegner, J. W. (2001). When workers flout convention: A study of workplace incivility, Human Relations, 54(11), 1387-1419.

Pearson, C. M. ve Porath, C. L. (2005). On the nature, consequences and remedies of workplace incivility: No time for 'nice'? Think again. Academy of Management Executive, 19(1),7-18.

Pekdemir, I. M., Sözüer, A., Yaşlığlu, D. T. ve Ceran, E. B. (2016). Yönetim ve organizasyon yazını üzerine inceleme: Bir anabilim dalı akademisyenlerinin 2005-2014 yılları arasındaki yayınları. İstanbul Üniversitesi İşletme Fakültesi Dergisi, 45, 81-99.

Polatcı, S. ve Özçalık, F. (2013). Yapısal ve psikolojik güçlendirmenin işyeri nezaketsizliği ve tükenmişliğe etkisi. İşletme Bilimi Dergisi, 1(2), 17-34.

Porath, C. L. ve Erez, A. (2009). Overlooked but not Untouched: How rudeness reduces on lookers' performance on routine and creative tasks. Organizational Behavior and Human Decision Processes, 109(1), 2944.

Porath, C. L. ve Pearson, C. M. (2010). The cost of bad behavior. Organizational Dynamics, 39(1), 64-71.

Porath, C. ve Pearson, C. (2013). The price of incivility, Harvard Business Review, 91(1-2), 115-121.

Reio, T. ve Ghosh, R. (2009). Antecedents and outcomes of workplace incivility: Implications for human resource development research and practice, Human Resource Development Quarterly, 20(3), 237-264.

Ricciotti, N. A. (2016). Emotional intelligence and instigation of workplace incivilityin a business organization. Walden Dissertations and Doctoral Studies. Walden University, USA.

Schilpzand, P., De Pater, I. E. ve Erez, A. (2016). Workplace incivility: A review of the literature and agenda for future research. Journal of Organizational Behavior, 37, 57-88.

Sezgin, F. ve Sönmez, E. (2018). Systematic investigation of organizational culture and climate studies: A content analysis. Inonu University Journal of the Faculty of Education, 19(1), 257-275. 
Shabir, M., Abrar, M., Baig, S. A. ve Javed, M. (2014). The contribution of workplace incivility and psychological capital toward job stress. International Journal of Human Resource Studies, 4(2), 1-17.

Spence-Laschinger, H. K., Leiter, M., Day, A. ve Gilin, D. (2009). Workplace empowerment, incivility and burnout: Impact on staff nurse recruitment and retention outcomes. Journal of Nursing Management,17(3),302-311.

Spence-Laschinger, H. K., Wong, C. A., Cummings, G. G. ve Grau, A. L. (2014). Resonant leadership and workplace empowerment: The value of positive organizational cultures in reducing workplace incivility. Nursing Economics, 32(1), 5-44.

Taştan, S. (2014). İşyeri nezaketsizliğini öngören örgütsel ve durumsal önceller ile çalışanların davranışsal sonuçları arasındaki ilişkinin ve sosyo-psikolojik kaynakların rolünün incelenmesi: Sağlık kurumlarında yapılan bir araştırma. İş, Güç Endüstri İlişkileri ve İnsan Kaynakları Dergisi,16(3),60-75.

Taylor, S. J. (2010). Cold looks and hot tempers: Individual-level effects of incivility in the workplace, Louisiana State University, Baton Rouge, LA.

Üstün, F. ve Ersolak, Ş. (2020a). Makyavelizm ve iş yeri nezaketsizliği: Banka çalışanları üzerine bir araştırma. IBAD Sosyal Bilimler Dergisi, 7 (yaz), 329-343.

Üstün, F. ve Ersolak, Ş. (2020b). Örgüt ikliminin işyeri nezaketsizliği üzerine etkisinde makyavelist kişilik özelliklerinin düzenleyici rolü. Atatürk Üniversitesi İktisadi ve İdari Bilimler Dergisi, 34(2), 433-460.

Welbourne, J. L., Gangadharan, A. ve Sariol, A. M. (2015). Ethnicity and cultural values as predictors of the occurrence and impact of experienced workplace incivility. Journal of Occupational Health Psychology, 20(2), 205-217.

Yalçınkaya, A. ve Türker, Y. (2016). Türk yönetim/örgüt yazınında örgüt kuramı çalışma alanı: 2002-2013 yılları arası bir değerlendirme. Ege Akademik Bakış, 16(3), 519-530.

Yildirim, A., Unal, A. ve Surucu, A. (2013). Incivil behaviours at school: Scale development. International Journal of Academic Research Part B, 5(3), 154-158. 


\section{Kaynakça Bilgisi / Citation Information}

Işıkay, Ç. ve Taslak, S. (2021). İşyeri nezaketsizliği: Ulusal literatür üzerine bir içerik analizi. OPUS-Uluslararası Toplum Araştırmaları Dergisi, 18(39), 521-552. DOI: 10.26466/opus.839745. 